\title{
Effectiveness of Trichogramma chilonis against Sugarcane inter node borer
}

\author{
A. Padmasri ${ }^{1}$, M. Sudh rani ${ }^{2}$ \\ Seed Research and technology centre, Rajendranagar, Hyderabad.
}

\begin{abstract}
Release of Trichogramma chionis Ishi (Hymenoptera;Trichogrammatidae), were made in one plot in regional sugarcane research station, Rudrur for biological control of internode shoot borers in sugarcane and compared with control plot.Perusal of data revealed that an average percent intensity of inter node shoot borer damage decreased to 70.70 and 53.87 per cent in 2011 and 2012 respectively and average percent incidence of inter node shoot borer damage decreased to 64.92 and 49.66 per cent in 2011 and 2012 respectively. Population of C. sacchariphagus indicus showed negative correlation with increase in number of parasitized eggs of T. chilonis, which indicates that it can be successfully used for the suppression of sugarcane Inter node shoot borer.
\end{abstract}

Key words: Egg parasitoid; Trichogramma chilonis; biological control, Chilo sacchariphagus indicus

\section{Introduction}

Sugarcane (Sacharum officinerum L.) is an important cash crop of India, Sugarcane crop provides raw cane to sugar mills which plays an important role in the economy of the country. Sugar serves as food and as most widely traded commodity. Sugar production in our country mostly depends upon sugarcane crop, though a small quantity of sugar is also produced from sugar beet. The average yield of sugarcane is low, may be due to many factors of which insect pest are the most important one. Insect pests are threat to sugarcane crop. Among these insect pests, about 103 insects are associated with Sugarcane (Kumarasinghe, 1999). Among these insect pests sugarcane borer are most damaging one. According to Aheer et al., (1994), stem borer of sugar cane causes losses up to $36.51 \%$. Sugarcane borer has become a challenging pest of sugarcane crop, due to feeding inside the plant parts where sprays are difficult to approach and the extensive and injudicious use of insecticides not only create the health hazards problem and environmental pollution but also resistance problem in large number of insect pests (Mohyuddin et al., 1997; Soerjani, 1998). It has been reported that more than 500 pest species have developed resistance against insecticides (Georghion and Lagunes, 1991). Indiscriminate use of pesticides kill the natural enemies resulting in flare up of pest population (Hamburg and Guest, 1997; Yousaf, 1996). To overcome resistance problem and also to meet the demand of international market, for producing good quality agro products, now more stress is on organic farming. It is imperative to use biological control programme for sugarcane. The inundative releases of bio agents for control of lepidopterous pests are being practiced in more than 32 million hectares each year around the world (Hassan,1993). T. chilonis releases in China, Switzerland, Canada and former USSR reduced the damage up to $70-92 \%$ on sugarcane, corn and cotton crops (Lily, 1994), while in Asia, releases of T. Chilonis remarkably reduced the incidence of cotton boll worm (Helicoverpa armigera) and sugarcane early shoot borer (Chilo infuscatellus) by 43 and $82 \%$, respectively (Bhut et al., 2004; Bharati and Babu etal., 2002). In sugarcane T. chilonis reduces stalk borer incidence by $55-60 \%$ (Shenhmar et al. 2003). The present study was designed to evaluate the relative efficacy of egg parasitoid T. chilonis Ishii against sugarcane Chilo sacchariphagus indicus.

\section{Material And Methods}

To evaluate the performance of egg parasitoid $\mathrm{T}$. chilonis for managing sugarcane inter node borer the experiment was conducted during 2011 and 2012 at Regional Sugarcane and Rice Research Station, Rudrur. Homogenous sets of standard commercial sugarcane variety Co 6907 was planted during last week of January every year in rows keeping $90 \mathrm{~cm}$ distance between set to set. Two treatments were imposed in two plots, each with acre area an isolation distance of 200 Meters between two plots was maintained. In one plot pre-determined number of parasitized eggs were released by installing $\mathrm{T}$. chilonis cards on fortnight basis in biological control plot. These cards were attached on ventral side of sugarcane leaves to avoid the direct exposure of sunlight to the parasitized eggs. First installation of card with parasitized eggs was done on july $15^{\text {th }}$ and last installation was done on $15^{\text {th }}$ october every year. The performance of egg parasitoid was evaluated based on the per cent incidence of inter node shoot borer after nine months of planting. Per cent intensity and incidence of internode shoot borer worked out by randomly selecting hundred clumps prior to release of egg parasitoid in selected locations and data were analyzed using paired $t$ test 
RESULTS AND DISCUSSION: During 2011 and 2012 results revealed that, sugarcane inter node shoot borer damage to canes in bio-control plot, where parasitoid, T. chilonis were released and compared with control. In treated plot per cent intensity of inter node shoot borer damage in 2011 and 2012 recorded 3.6 and 6.6 with 5.1 mean per cent intensity of inter node shoot borer while, in check plot recorded 12.29 and 14.31 with 13.3 mean percent intensity of inter node shoot borer. Per cent reduction over the control plot recorded was 70.70 and 53.87 in 2011 and 2012 respectively.

The per cent incidence of inter node shoot borer in treated plot recorded in2011 and 2012 was 17.45 and 2.53 with mean percent incidence of inter node shoot borer 18.99 per cent. While, in check plot per cent incidence of inter node shoot borer was 40.79 and 49.75 per cent with mean per cent incidence of 45.27 . The per cent reduction of incidence of inter node shoot borer in treated plot over the check plot was 49.66 and 64.72 per cent in 2011 and 2012 respectively. The yield in treated plot was $83.33 \mathrm{t} / \mathrm{ha}$ ant 78.69t/ha in 2011 and 2012 respectively, while in check plot was $73.42 \mathrm{t} / \mathrm{ha}$ and $74.64 \mathrm{t} / \mathrm{ha}$.

Comparison of results among the sites showed the effectiveness of $\mathrm{T}$. chilonis in suppression of borer pests in bio-control plots were at par to economic threshold level. Further more as our results showed that on large scale area at farmer field the bio-control with T. chilonis is successful. Our results are in the line to the results reported by Ashraf et al. (1993) that borer damage in canes on inter node basis at the time of harvest was in the range of 4 to $35.5 \%$ with an averageof $14.1 \%$. The inundative releases of T. chilonis in experimental plots reduced the borer infestation to $4.2 \%$ as compared to check plots with $16.2 \%$ infestation. The results of present study was in agreement to the findings of Ashraf et al. (1995) who reported that the borer damage on internodes basis ranged from 4.2 to $6.8 \%$ in treated plots by T. chilonis as compared with 15.7 to $24.6 \%$ in the control on variety BL-4. Results reported by Rana et al. (2007) are nearly at par to our findings that got 11.33 and $12.65 \%$ borer damage to canes in year 2002 and 2003 in check plots, respectively, while 6.75 and $6.4 \%$ in year 2002 and 2003 in T. chilonis released plots respectively. Mishra et al. (1997) have reported borer damage of 9.8 and $12.6 \%$ in 1994 and 1995, respectively; these results are in the line of our study. It was inferred from the present study that inundative weekly releases of $\mathrm{T}$. chilonis in sugarcane crop for suppression of borer pests has gave effective control measure without any side effects to the crop and environment.

\section{References:}

[1]. Aheer, G.M., H. Ahmad, M. Ashfaq and M. Jalali, 1994. Weather effect on population dynamics of top borer, Scirpophaga nivella and stem borer, Chilo infuscatellus on sugarcane crop. J.Agric. Res., 32 (4): 411- 420.

[2]. Ashraf, M., B. Fatima and N. Ahmad, 1993. Control of sugarcane by inundative releases of Trichogramma chilonis (Ashii). Pak. J.Zool., 25 (1): 23-25.

[3]. Ashraf, M., B. Fatima and S.S. Ali. 1995. Significance of Trichogramma chilonis (Ishii) in controlling the sugarcane borers. Proc. Pak. Congr. Zool. 15:171-176.

[4]. Georghion, G.P. and T.A. Lagunes, 1991. The occurance of pesticides in arthropods. Food Agric.Org., pp: 318

[5]. Hamburg, H.V. and P.J. Guest, 1997. The impact of insecticides on beneficial arthropods in cotton agroecosystem in South Africa. Archives environ. Contamin. Toxic., 8(8):786.

[6]. Hassan, S.A., 1993. The mass rearing and utilization of Trichogramma to control lepidopterous pests: Achievements and outlook. Pestic. Sci., 37: 387-91.

[7]. Kumarasinghe, N.C., 1999. Insect fauna associated with sugarcane plantations in Sri lanka Division of Pest Management, Sugarcane Research Institute, Uda Walawe, Srilanka.

[8]. Lily, 1994. World wide use of Trichogramma for biological control on different crops. Surv. Sec. Ref., 205. pp: $37-51$.

[9]. Mishra, B.K., N. Nayak, P.K. Das, S.S. Mohapatra and B.C. Jena. 1997. Biological control of sugarcane borers through Trichogramma chilonos (Ishii) in Nayagarh District of Orissa. Indian Sugar 46:797-798.

[10]. Mohyuddin, A.L., G. Jilani, A.G. Khan, A. Hamza, A. Ahmed and Z. Mahmood, 1997.

[11]. Integrated pest management of major cotton pests by conservation, redistribution, and augmentation of natural enemies. Pak. J. Zool., 29 (3): 293-298.

[12]. Rana, Z.A., I. Haq, N.A. Malik and A.S. Akhtar. 2007. Effects of trash mulching and Trichogramma chilonis (Ishii) on sugarcane borers infestation. J. Agric. Res. 45:161-164.

[13]. Shenhmar, M., J. Singh, S.P. Singh, K.S. Brar, D.Singh, P.L. Tandon, C.R. Ballal, S.K. Jalali and R.J. Rabindra, 2003. Effectiveness of Trichogramma chilonis Ishii for themanagement of Chilo auricilius Dudgeon on sugarcane in different sugar mill areas of the Punjab. Biological control of lepidopteran pests. Proceed. Sympos. Biol. Contr. Of Lepidopteran Pests, July 17-18, 2002 Bangalore, India. pp. 333-335.

[14]. Soerjani, M., 1998. Current trend in pesticide usage in some Asian countries. Environ. Implic. Res. Pestic. Intern. Atomic Energy Agency, Vianna Austria. pp: 219-234. 
Table 1 : Evaluation of Trichograma chilonis against sugarcane internode borer.

\begin{tabular}{|c|c|c|c|c|c|c|c|}
\hline year & Treatments & $\begin{array}{c}\text { percent } \\
\text { intensity of } \\
\text { INB }\end{array}$ & $\begin{array}{c}\% \% \\
\text { reduction } \\
\text { in } \\
\text { intensity } \\
\text { of INB }\end{array}$ & $\begin{array}{l}\text { percent } \\
\text { incidence }\end{array}$ & $\begin{array}{l}\% \\
\text { reduction in } \\
\text { incidence of } \\
\text { INB }\end{array}$ & $\begin{array}{l}\text { Yield } \\
\text { t/ha }\end{array}$ & $\begin{array}{l}\% \text { Increase } \\
\text { over control }\end{array}$ \\
\hline \multirow[t]{2}{*}{2011} & $\begin{array}{l}\text { T1=Trichogramma } \\
\text { released plot }\end{array}$ & 3.6 & & 17.45 & \multirow{2}{*}{64.92} & 83.33 & \multirow{2}{*}{11.89} \\
\hline & $\begin{array}{l}\mathrm{T} 2=\mathrm{control} / \\
\text { untreated plot }\end{array}$ & 12.29 & 70.70 & 49.79 & & 73.42 & \\
\hline \multirow[t]{2}{*}{2012} & $\begin{array}{l}\text { T1=Trichogramma } \\
\text { released plot }\end{array}$ & 6.6 & \multirow[t]{2}{*}{53.87} & 20.53 & \multirow{2}{*}{49.66} & 78.69 & \multirow{2}{*}{5.14} \\
\hline & $\begin{array}{l}\text { T2 }=\text { control } / \\
\text { untreated plot }\end{array}$ & 14.31 & & 40.79 & & 74.64 & \\
\hline \multirow[t]{3}{*}{ Mean } & $\mathrm{T} 1$ & 5.1 & & 18.99 & & 80.98 & \\
\hline & $\mathrm{T} 2$ & 13.3 & & 45.27 & & 74.03 & \\
\hline & $\mathrm{t}-\mathrm{cal}$ & 5.28 & & 6.67 & & 2.43 & \\
\hline
\end{tabular}

Fig1 : Evaluation of Trichograma chilonis against sugarcane internode borer.

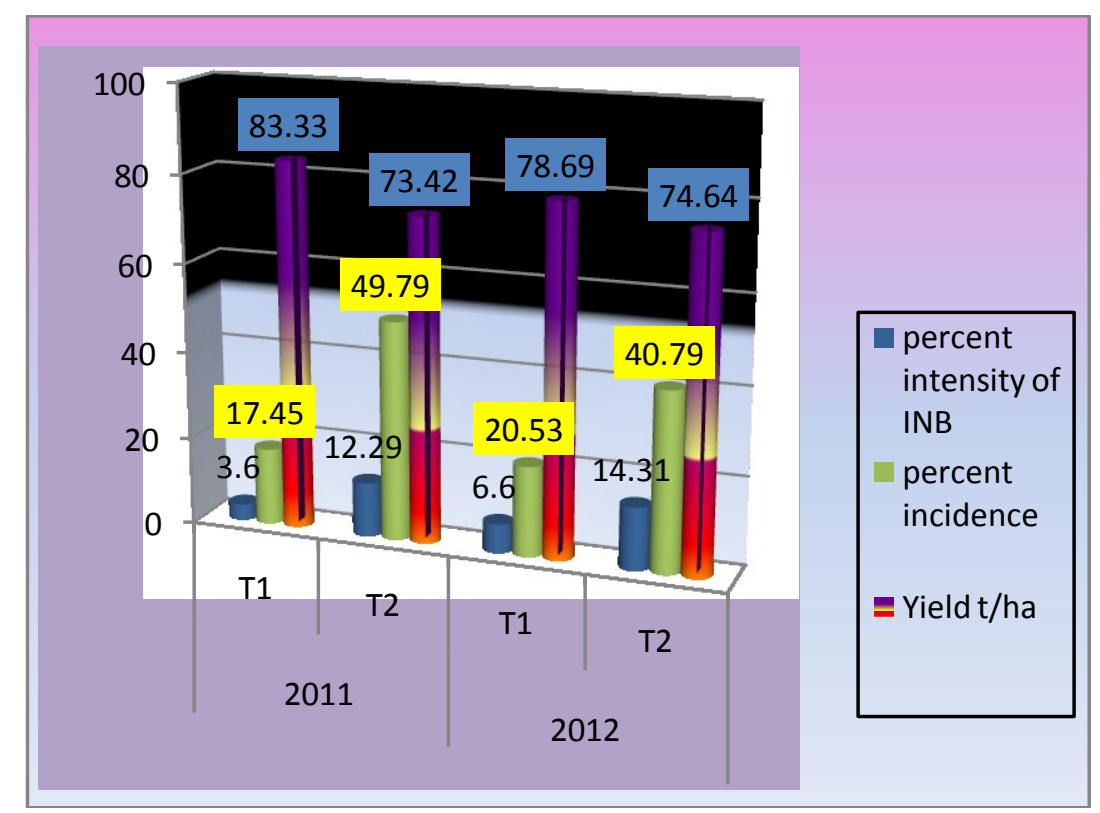

T1 $=$ Trichogramma released plot

$\mathbf{T} 2=$ Control plot 